\title{
An Error Analysis of Tense Errors in English Major Undergraduates' Translations
}

\author{
Xinran $\mathrm{Li}^{1, \text { a, }}{ }^{*}, \dagger$, Yutong Zhao ${ }^{2, \mathrm{~b}, *, \dagger}$ \\ ${ }^{1}$ School of Bachelor of International Tourism Management, Macau University of Science and Technology, Macau, \\ 999078, China \\ ${ }^{2}$ Department of English and International Studies, China Foreign Affairs University, Beijing, 100037, China \\ ${ }^{*}$ Corresponding author. Email: ${ }^{a} 1809853 w b 1110053 @$ student.must.edu.mo, ${ }^{b} 15001363351 @ 163 . c o m$ \\ These authors contributed equally.
}

\begin{abstract}
Tense errors in translation works are of great importance because it affects the transmission of the original texts and plays a big part in research of Second Language Acquisition. The authors of this article used the method of Error Analysis to analyze errors of tenses in translation works of English major undergraduates from China. Then, they conducted interviews with 3 students who provided their works and made a questionnaire to deeply explore causes of errors. The authors found that the target students still made errors about tense even if they have a better command of English and are aware of the difference between Chinese tenses and English tenses. Six possible reasons are demonstrated: (1) different tense morphological features; (2) lack of adverbial of time; (3) difficulties to contextualize; (4) translators' misunderstanding about tenses; (5) translators' habits and preferences; (6) overlaps of concepts between some tenses. The acquisition of tenses in English is related to both the transfer between Chinese and English and students' learning experience. Inefficient correction methods should be highlighted because it is difficult for students to find errors in tenses themselves. However, self-study still serves as the most common and effective way for them to learn more about tenses.
\end{abstract}

Keywords: Error Analysis, Tense, Chinese-English Translation, Interview, Questionnaires.

\section{INTRODUCTION}

Nowadays, to meet the need to integrate into the world market and comply with the global environment, China has spent considerable energy and money on foreign languages. Many Chinese students choose English or Translation as their major in universities because of the role of English as the most popular language in the world's political, economic, and cultural fields. Therefore, research on second language acquisition for Chinese learners of English is receiving increasing attention. As the bridge between Chinese and English, translation works where tense errors can be found as the phenomenon of SLA (Second Language Acquisition) to study of great importance. This article will focus on translations of English major undergraduates in China's universities, aimed at exploring what obstacles and difficulties remain even though they are very aware of the need to change tenses and, as English majors, have a great deal of grammatical knowledge.

\section{LITERATURE REVIEW}

For years, the study of the comparison or the transfer between Chinese and English are very popular because they have different language systems, from spelling to grammar, causing barriers for learners in the process of SLA.

In the field of research of SLA, the study of learner's errors has always been regarded as a dominant approach to analysis. Richard once proposed that analyzing errors serves as an effective way to study the process and condition of learners because errors are, in fact, normal and inevitable features indicating the strategies that learners use instead of problems that should be overcome [1]. Hence, analyzing errors of tenses deeply can directly reveal the fundamental reasons for the phenomenon in SLA. One thing that should be emphasized is that the concept of "error" is different from that of "mistake". In Corder's opinion, errors can be divided into mistakes and the systematic errors of the learner or his transitional 
competence as errors [2]. Hinkel observed that an error is a deviation from the norms of the Target Language (TL), and it is difficult to be self-corrected [3]. Therefore, errors selected by this article will not contain simple mistakes caused by factors such as carelessness.

According to McCarthy, among all the errors, tense is a main and common barrier for learners to acquire a foreign language [4]. Therefore, errors of tenses that learners make have always been important. However, in past relevant studies, the targeted groups were always elementary learners of English, such as elementary and junior high school students, for whom the most important cause of errors is a lack of understanding of the English and Chinese tense systems and lacking need for tense transfer. For example, $\mathrm{Gu}$ analyzed senior teacher training students (high school equivalency in China), the data showed that tense errors accounted for $24 \%$, and the main reasons were students' limited vocabulary and weak grammatical skills [5]. As a result, this article targets English major undergraduates who have already passed the CET-6 test, possessing a relatively better command of English to weaken the influence of reasons mentioned above.

In addition, students' writings used to be the primary data due to their well-obtained and intuitive nature. Instead of collecting writings of students, this article will use English major undergraduates' translations because translation is a process when they have a purpose of converting the two languages and the two cultures between Chinese and English, which is more suitable for exploring why English major undergraduates still make errors about tenses. However, they pay close attention to them. Also, in Tytler's three principles of translation, making sure the merit of the original text can be translated completely and be felt strongly by a native of the target language is a top priority of translation [6]. Because misuse of tenses may lead to misunderstanding of the original text, studying tense errors in translations works is significant.

\section{METHODS}

This article will adopt the method of error analysis. Totally, 11 tense errors in 68 translation works have been collected from 8 undergraduates from the English Department of China Foreign Affair University, China. To investigate more deeply the causes, the authors also conducted interviews with three of the eight undergraduates who provided their translation works. The interviews were conducted in the form of speech and consisted of seven questions relevant to the translation works they provided.

In addition, a questionnaire has been made to collect more information about their own's recognition of tenses. Finally, 50 answers to the questionnaire were obtained from English major students at China Foreign Affair
University, China Foreign Affairs Training Institute, Macau University of Science and Technology, etc.

\section{RESULTS}

\subsection{Translation Works}

In all 68 translation (Chinese-to-English) texts from 8 English major undergraduates the authors have collected, 11 obvious tense errors have been found. It should be noted that grammar is only one of the possible usages of language that suits most of the conditions and principles. It cannot be regarded as the only measure of a person's mastery and application of a language. It is inappropriate to decide any usages that are in accordance with grammar books are wrong. However, in the field of translation, since the original text of the Source Language (SL) has already defined the meaning of the text, the translator can find a usage of the TL that is most appropriate compared with other versions in most cases. That also explains why this article chooses translation as its primary examples instead of writing, including free creation.

To analyze the errors found in different translations of different translators(students), this article will divide them into three categories: (1) translation of texts describing facts; (2) translation of continuous events or actions; (3) translation of specific types of texts. Here are the details of each error.

\subsubsection{Translation of Texts Describing Facts}

(1) SL: 在许多城市, 当局要求灵活的办公时间和 错班，帮助工作人员避开繁忙的公共交通时间和高 峰通勤时间。用餐时间, 只有少数人在食堂里, 所有人 都被隔开一米多的距离, 严格禁止谈话。不少公司 都会检查员工的体温，并鼓励员工自带餐具。

TL: In many cities, the governments require flexible and staggered office hours to help workers avoid busy public transportation and rush-commuting hours. Only a few people were in the canteen at mealtimes, while all of them were separated by more than a meter distance and talking was strictly forbidden. Many companies will check their employees' body temperature and encourage them to bring their own cutlery.

(2) SL: 用餐时间,只有少数人在食堂里。所有人都 被隔开一米多的距离, 严格禁止谈话。

TL: Only a few people are in the cafeteria at mealtime. All the people were more than a meter away from each other, and talking was strictly forbidden.

(3) SL: 由于疫情的影响, 企业不得不关闭空调和 新风系统, 所以最受欢迎的员工福利是必不可少的 加热宝。

TL: As a result, an indispensable small heater became the most popular welfare for employees. 
Error: The original text is about the efforts to control the COVID-19. As a result, the use of tense needs to be unified rather than select tenses based on each sentence. Without any adverbial of time in the original text, the translator needs to decide the best choice of tense according to what the text aims to express. For the description of the facts during the epidemic, the simple present tense is more appropriate.

\subsubsection{Translation of Continuous Events or Actions}

(1) SL: 中国具有五千年悠久历史, 中华民族繁衍 生息在中国这块土地上。

TL: China has a long history of about five thousand years. The Chinese nation is living and prospering on this land.

(2) SL: 中国具有五千年悠久历史, 中华民族繁衍 生息在中国这块土地上。

TL: China has a long history of 5000 years. Living on the land of China, different Chinese ethnicities integrated with each other.

Error: In the original Chinese text, “五千年” (5 thousand years) is a typical hint of time in Chinese, representing a long period from the beginning of the Chinese nation to today. Unlike the previous 3 examples, the translator can choose the proper tense with the help of “五千年”. In such a context, the present continuous tense is not the best choice. To some extent, the present perfect tense or present perfect progressive is better to retell Chinese expression because they also include what happened in the past.

(3) SL: 近日, “外卖小哥” 的话题又热了起来。 作为一种新兴行业, 送外卖越来越成为许多人的就 业选择。

TL: Recently, "delivery boy" has once again become a popular topic of discussion. As a burgeoning industry, food delivery has increasingly become a career choice for many people.

(4) SL: 同时, 外卖配送也越来越成为一个年轻人 聚集的新兴行业, 青年们依靠送外卖, 就能在城市 暂时站稳了脚跟。

TL: At the same time, food delivery has increasingly become a burgeoning industry that engages young workers.

Error: Although it cannot serve as an adverbial of time, the Chinese expression "越来越" (more and more) represents a dynamic development that has not yet stopped and is still in progress so that it is more suitable to use the present continuous tense.
(5) SL: 坚持 “老药新用” 基本思路，积极笁选有 效治疗药物, 探索新的治疗手段, 在严谨的体外研 究和机制研究基础上，不断总结救治经验。

TL: We will uphold the basic principle of "new usage of past medicine", actively select effective medicine, and explore new therapies. And we will summarize treatment experience based on serious external-body research and mechanism research.

Error: This example is a piece of independent sentence translation practice for the Chinese translation qualification exam. Since there is no adverbial of time in the original Chinese text and no other relevant sentences in the context, the translator needs to judge according to the meaning of this paragraph. She misused the present perfect in sentences that should have been translated into present perfect progressive. This text aims to narrate new usages of past medicine invented during the COVID-19, which are no plans for the future but efforts already made.

(6) SL: 新中国成立以来，中国坚持从国情出发, 在承继中国传统法律文化优秀成果、借鉴人类法治 文明的基础上，探索建立并不断完善中国特色社会 主义司法制度，维护了社会公正，为人类法治文明 做出了重要贡献。

TL: Since the founding of the People's Republic of China, we have considered China's realities, explored, and improved the socialist judicial system with Chinese characteristics based on the law of traditional China and other civilizations. Therefore, we have safeguarded social justice and contributed to the law culture of human beings.

Error: Still, without hints of adverbial time, the student should pay close attention to the context. Instead of present perfect, present perfect progressive is better because the original text emphasizes the continuous efforts of China from 1949 to the future. “不断” (emphasizing the continuation of the efforts) in the original text can serve as a signal to use present perfect progressive.

\subsubsection{Translation of Specific Types of Texts}

(1) SL: 北京的道旁多植槐树, 当槐花 (blossoms) 挂满枝Y香飘四溢的时候，夏日就带着炎热和浓绿 向人们涌来了。清晨, 骑上自行车, 加入上班 “洪 流”，眼前闪动的是五颜六色的夏服。

TL: There are many locust trees are planted along the roads in Beijing. When the branches are full of blossoms, the fragrance drifts through the city, summer flocks to people with scorching heat and thick green. Early in the morning, get on your bike and join the rush to work, what flashed before your eyes are colorful summer clothes.

Error: This text comes from a Chinese literary work. With no help from the adverbial of time, the translator should decide which tense is better according to the 
norms of literature translation. In such a paragraph describing the facts and events in summer in this novel, the simple present tense should be used consistently instead of the simple past tense and the simple present tense.

(2) SL: 随着中国政府相继对香港、澳门恢复行使 主权, 全中国人民迫切希望早日解决台湾问题, 实 现国家的完全统一, 不能允许台湾问题再无限期地 拖下去了。

TL: With the Chinese government resuming the exercise of sovereignty over Hongkong and Makao in succession, all Chinese people have an urgent desire to resolve Taiwan-related issues and achieve China's complete reunification. We will not allow these issues to be dragged on for an indefinite period.

Error: This text belongs to political and diplomatic text obviously to express Chinese people's strong desire for cross-strait reunification and their firm opposition to any infringement of China's sovereignty. Therefore, the use of the general future tense is not appropriate. In diplomatic texts, the simple present tense should be chosen for such sentences that express the people's strong will today. Otherwise, "will" may turn the meanings of the text into plans or measures so that what the text aims to express cannot be transferred with a firm and solid tongue.

\subsection{Interviews}

To investigate more deeply the causes of tense errors in translations made by college students majoring in English, the authors also conducted interviews with a sample of three of the eight students who provided their translation works. The interviews were conducted in the form of speech and consisted of the following seven questions: (1) Have you already realized what tense error(s) you made in this translation? (2) How did you know that (for example, through self-checking, answer prompts, peer discussion, teacher review, etc.)? (3) Are you confused about the reason for the error(s)? (4) Why did you translate it this way at that time? (5) What do you think caused this(these) error(s)? (6) Do you think such an error is important? (7) How would such an error affect the translation if it occurred?

In the analysis of the errors, all three students could not find the errors themselves, even though they had checked the target text after translation. But after reading the standard answers and discussing them with their classmates, they accepted the reasons for their errors and reflected on them.

Two of the interviewees made similar errors in translating texts describing facts, misusing the simple present tense and the simple past tense. They both thought that the events or actions mentioned in the original text happened in the past and have been finished, so they need to use the simple past tense. In addition, since there is no adverbial of time in the original text, some sentences are difficult to determine exactly what tense should be used according to the meaning of the text, so there is a mix of multiple tenses. What is more, their writing habits also play an important part. They both mentioned that the simple past tense is very common, and they use it in their speaking and writing.

Another interviewee also mentioned the influence of her habits. This interviewee made a total of two tense errors in the collected translations, both regarding the translation of continuous events or actions. No matter in speaking, writing, or translation, she does not often use the present perfect tense for fear of making mistakes. The simple future tense is her preference because she does not have to worry about changing the singular and plural, and it is easier to use. As for the present perfect progressive tense, she thought it is too uncommon in daily life; as she does not quite understand the differences between it and the present perfect tense, her translation work seldom showed distinctions between these two tenses.

All three interviewees suggested that these tense errors in their translations were important due to unclear examination of the text. For example, two interviewees mentioned that sometimes they did not read the original text carefully enough. Also, the other interviewee emphasized her translation experience that made her think about the problem in an easy way. When she sawed expressions like “坚持老药新用”, she subconsciously assumes that this is the tone of a leader giving instructions, because she has done so much practice translating diplomatic texts in her major courses.

They all agreed that studying tense errors is very meaningful and that it is necessary to study tenses carefully in translation. They have also been very serious and careful about this because errors in tense can cause wrong paraphrasing of the original text, especially in the case that there is no complete tense system in Chinese.

\subsection{Questionnaire}

\subsubsection{The Design of Questionnaire}

This article takes 50 English Majors from different universities in China as the research objects in the 2018 class, including 12 students from the Macau University of Science and Technology and 28 students from the China Foreign Affairs University. A questionnaire was designed to explore in detail which tenses these 50 English majors are prone to make mistakes. We have selected the three most valuable research questions for discussion. Exploring these three questions aims to find out tense mistakes commonly made by English majors and study suggestions. 


\subsubsection{Types of Errors}

To know more information about English Major Students' own recognition of tenses, the first question we chose is "which tenses are the most difficult to learn for you?" According to the basic forms of English tense, the tense errors of the research objects are divided into 8 types: subjunctive, future progressive tense, present perfect tense, past perfect tense, past tense, past progressive tense, none, and perfect tense. Specific information is shown in Table 1, Table 2, and Table 3.

Table 1. The Tenses with The Highest Learning Difficulty and Their Selection Frequency

\begin{tabular}{ll}
\hline Tenses & Numbers of Errors \\
\hline subjunctive & 9 \\
future progressive tense & 6 \\
present perfect tense & 9 \\
past perfect tense & 11 \\
past tense & 4 \\
past progressive tense & 1 \\
none & 4 \\
perfect tense & 6 \\
Total Options & Total Respondents: 50 \\
\hline
\end{tabular}

Table 1 gives information about how the tenses with the highest learning difficulty and respondents' choice varies. A total of 11 respondents chose the past perfect tense as the most difficult tense to learn, which was almost 2 times that of future progressive tense and perfect tense. Other high-frequency options also related to subjunctive, perfect tense. It is challenging for English learners whose mother tongue is Chinese to change from the Chinese language habit of expressing the past tense and perfect to the English expression habit [7]. Therefore, the language processing mechanism of Chinese L2 is different from that of native speakers.

Table 2. The Most Common Errors Respondents Make about Tenses

\begin{tabular}{lll}
\hline Tenses & Numbers & Percentages \\
\hline $\begin{array}{l}\text { present sense } \\
\text { present perfect }\end{array}$ & 3 & $6 \%$ \\
$\begin{array}{l}\text { tense } \\
\text { present }\end{array}$ & 8 & $16 \%$ \\
$\begin{array}{l}\text { progressive } \\
\text { tense }\end{array}$ & & $2 \%$ \\
$\begin{array}{l}\text { past tense } \\
\text { past perfect }\end{array}$ & 4 & \\
$\begin{array}{l}\text { tense } \\
\text { past progressive } \\
\text { tense }\end{array}$ & 4 & $8 \%$ \\
$\begin{array}{l}\text { general future } \\
\text { tense } \\
\text { future } \\
\text { progressive } \\
\text { tense }\end{array}$ & 1 & $34 \%$ \\
Total options & 12 & $8 \%$ \\
& $\begin{array}{l}\text { Total } \\
\text { respondents: } 50\end{array}$ & $100 \%$ \\
\hline
\end{tabular}

As shown in Table 2, the biggest percentage was distributed to the figure of "past perfect tense", which made up $34 \%$ of the total. $24 \%$ was allocated for the "future progressive tense" figure, which was the secondlargest proportion. In contrast, the figure of "present progressive tense" and "general future tense" had the same percentage at $2 \%$, the smallest part of the total. Besides, the percentage of errors on present sense, past sense and past progressive tense shared similar percentage, with $6 \%, 8 \%$ and $8 \%$ respectively. In terms of the proportion of errors on present perfect tense, it comprised $16 \%$ of the total. Obviously, respondents were better at dealing with English tenses that are highly similar to Chinese tenses. In Chinese, the expressions of present and future tense are generally similar to those in English, and the form of change is relatively simple.

Table 3. The Methods Respondents Try to Use to Correct Tense Errors

\begin{tabular}{lll}
\hline Methods & Numbers & Percentages \\
$\begin{array}{l}\text { Asking teacher } \\
\text { discuss with }\end{array}$ & 10 & $20 \%$ \\
$\begin{array}{l}\text { classmates } \\
\text { studying online }\end{array}$ & 9 & $8 \%$ \\
self-study & 27 & $18 \%$ \\
Toral options & $\begin{array}{l}\text { Total } \\
\text { respondents: } 50\end{array}$ & $\begin{array}{l}\text { Total percentage: } \\
100 \%\end{array}$ \\
\hline
\end{tabular}

Table 3 illustrates how the methods respondents try to use to correct tense errors varies. 54\% was allocated for the percentage of self-taught people. As adults, these respondents have a certain degree of self-learning ability. Moreover, it is unrealistic to ask teachers and classmates for help when encountering any problems during college. It can also be seen from Table 3 that more than half of the respondents are more inclined to self-study to solve tense problems [8].

\section{DISCUSSIONS}

\subsection{Discussions about the Translations and the Interviews}

According to the examples of translation works and interviews above, we can find that the translators are aware of the need to transfer tenses between Chinese and English and have made lots of efforts. However, errors still exist in these translation works. Generally speaking, those errors are not caused by the students' neglect of tenses, which is the dominant reason why younger students or English learners have little knowledge about grammar. According to the results above, six possible reasons can explain for the phenomenon.

First, Chinese tense morphological features are different from English [9]. The main thing that changes in English past tense or perfect tense is the verb. While Chinese usually uses auxiliary verbs or words that express time to define the tense, but the verb does not change [10]. Therefore, it is difficult for English learners who speak Chinese as their mother tongue to use the past tense and perfect tense flexibly compared with a native speaker. 
Second, there is no adverbial of time in the original text. In total, there are 2 examples of errors with hints from adverbial of time in the original text and 9 examples without any adverbial of time. Hence, it is obvious that whether there exists an adverbial time to determine the tense selected for the text in the original Chinese source is important, causing direct influence on students' error rates. Eckman suggested that transfer was most pronounced when the native language parameter was unmarked and the target language was marked [11]. Wang and $\mathrm{Li}$ found that the verb tense marker is a necessary component of English, whereas, in Chinese, it is unmarked [12]. Therefore, the adverbial of time plays a significant role in Chinese students' acquirement of English tenses.

Third, it is hard for L2 learners to contextualize their translation works. Different types of texts embrace different norms of translation, so that the translator should choose the appropriate tense according to the purpose of the translation (literature, diplomatic, business, medical, etc.). If one fails to obey the norms of different types of translation, errors occur easily. In this way, the translation of tenses has been turned from a grammar test into a test of culture and pragmatics, which are the most difficult part for $\mathrm{L} 2$ learners to acquire.

Forth, L2 learners have misunderstandings when learning tenses. Saville-Troike thought that L2 speakers have an incomplete for the partial theory of tense and cannot get rid of the prior knowledge of L1 [13]. Additionally, for test-taking, L2 learners of English in China study lots of "practical" skills, which are not applicable in all cases. For example, one of the interviewees prefers to use the simple future tense because it is not error-prone. Similar "tricky skills" can be found in China's English course. Many English teachers ask students to recite some tricks to understand tenses with some keywords. For example, when teaching the simple past tense, they told students to use it as long as they notice “了” or “已经”, causing troubles when teaching the present perfect tense because these two tenses share the same iconic words in Chinese. As L2 learners of English, these teachers themselves have not fully acquired the grammar and pragmatics of English, and the tricks they summarize are not always correct. In the process of learning, misunderstandings gradually arise.

Fifth, the personal habits of the translators also play a large part in reason. According to the interviews, some translators use simpler and more common tenses, such as the simple past tense and the simple future tense. They may subconsciously choose to use the tenses they are accustomed to when they see typical signals or specific content in the text, ignoring the specificity of each text and failing to correctly analyze the meaning of the original text. Similar reasons for errors can be found in another research. Newbery-Payton and Mochizuki also observed that Chinese learners of English easily make errors of tenses due to their misinterpretation of ongoing habits. They get used to applying unnecessary tense marking despite the adverbials "since then" and "now" [14].

Sixth, the English tense system itself causes obstacles for Chinese students. Although people do use some auxiliary words to indicate the completion of an action in Chinese, it is very simple compared to the English tense system. The two languages have completely different and distinctive tense systems, making sense one of the most important barriers for L2 learners. For example, Zhao and Liu once found that what is expressed by two or more tenses of English overlap so that the most confusing ones for Chinese students are generally present perfect, simple past, and the simple present tense, which is indistinguishable [15].

\section{CONCLUSION}

This article discusses the mastery of English tenses and the self-assessment of English majors. In China, most colleges and universities have established English majors. As the English tense is one of the biggest obstacles for non-native English learners, by investigating the mastery of the tense of English majors and the error correction methods in the learning tense, this paper infers and analyzes the reasons why English majors still have difficulties in learning the tense by interviewing respondents and distributing the questionnaire. The main reason for it is the difference in linguistic thinking and language models between Chinese and English. Only by finding the true cause of the difficulty in mastering tense can we find the correct and effective way to solve it.

\section{REFERENCES}

[1] Richards, J. C. (1974). A non-contrastive approach to error analysis. Error analysis: Perspectives on second language acquisition, 172-188.

[2] Corder,S.P.(1974) The significance of learners'errors. In Jack C. Richards (Ed.) Error Analysis: Perspectives on Second Language Acquisition (pp. 24-30). London: Longman.

[3] Hinkel, E. (1997). The past tense and temporal verb meanings in a contextual frame. TESOL Quarterly, 31(2), 289-313.

[4] McCarthy, M. (1991). Discourse analysis for language teachers. Cambridge University Press, 62.

[5] Gu, M. J. (2020). Analysis of English grammatical errors of higher vocational teacher training students - An example from Yangjiang Vocational and Technical College. Journal of Xiang Yang 
Polytechnic(02),56-59+76.

doi:CNKI:SUN:XFZY.0.2020-02-016.

[6] Tytler, A. F. (1978). Essay on the Principles of Translation (1813): New edition (Vol. 13). John Benjamins Publishing, 15 .

[7] Zhang, Y. (2020). Differences Between Chinese and Western Thinking Modes and English Writing. Journal of Chengde Petroleum College (04),82-86.

[8] Fan, M, Zhao, S.X. (2021). Research on the Correlation between Formative Assessment and Self-efficacy of Non-English Majors. Journal of Bengbu University (04),92-96.

[9] Babcock, L.; Stowe, J.C.; Maloof, C.J.; Brovetto, C.; Ullman, M.T. (2012). The storage and composition of inflected forms in adult-learned second language. Cambridge University Press, 820840 (21).

[10] Hu, H.L. (2020). A Study on the Minor Changes of Tense Correction in College English Writing. English Square, 2020 (27) , 36-38.

[11] Wang, W. B. \& Li, W.W. (2021). A study on the relationship between the temporal gerund and the general past tense in Chinese higher-level English acquisition - A perspective on the difference between English and Chinese temporality. Foreign Language Education(04),1-7. doi:10.16362/j.cnki.cn61-1023/h.2021.04.001.

[12] Eckman, F. R. (1977). Markedness and the contrastive analysis hypothesis. Language learning, 27(2), 315-330.

[13] Saville-Troike, M., \& Barto, K. (2017). Introducing second language acquisition. Cambridge University Press, 18-19.

[14] Zhao, X.D. \& Liu, Y. (2012). A Corpus-based Analysis of Tense Errors in Chinese College English Major Students' writing. Journal of Liaoning Normal University (Social Sciences Edition)(04),540-545. doi:CNKI:SUN:LNSS.0.2012-04-025.

[15] Newbery-Payton, L., \& Mochizuki, K. (2020). L1 Influence on Use of Tense/Aspect by Chinese and Japanese Learners of English. Learner Corpus Studies in Asia and the World, (4), 67-93. 